\title{
The effect of ulinastatin on sepsis in the rats of adhesion molecules and endothelial function
}

\author{
$X \mathrm{Hao}^{1 *}, \mathrm{G} \mathrm{Cai}^{2}, \mathrm{CHu}^{2}$ \\ From ESICM LIVES 2015 \\ Berlin, Germany. 3-7 October 2015
}

\section{Objectives}

To understand the effect of ulinastatin on protecting vascular endothelial cell in sepsis rats and its mechanism.

\section{Methods}

Fifty-two rats were: randomly divided into A(ulinastatin group, $n=26$ ), $B$ (NS, normal saline group, $n=26$ ). $18 \mathrm{~h}$, $3 \mathrm{~h}$ before LPS injection, both groups were pretreated with ulinastatin $(100,000 \mathrm{U} / \mathrm{kg}$, dissolved in normal saline of $5 \mathrm{ml}$ )and NS (normal saline, $5 \mathrm{ml}$ ), respectively. At the time of $1 / 2 \mathrm{~h}, 2 \mathrm{~h}, 4 \mathrm{~h}, 12 \mathrm{~h}, 24 \mathrm{~h}, 72 \mathrm{~h}$, to measure the level of TNF- $\alpha$, IL-6, IL-10, VCAM and ICAM-1.

\section{Results}

Compared with group A, the level of TNF- $\alpha$ and IL-6 were increased significantly in group $B(P<0.05)$; the level of IL-10 were decreased significantly in group $\mathrm{B}(\mathrm{P}$ $<0.05)$. The level of VCAM, ICAM-1 in group A were significantly lower than those in group $B(P<0.05)$.

\section{Conclusions}

Ulinastatin can reduce the mortality of sepsis, its mechanism may be to inhibit the inflammatory response, reduce the release of pro-inflammatory cytokines, promote the expression of anti-inflammatory cytokines and to inhibit the expression of selection, adhesion molecules and angiopoietin receptor, thus it can inhibit the adhesion of inflammatory cells and endothelial cells to improve microvascular permeability and protect the function of endothelial cells.

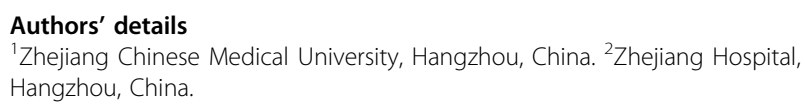

'Zhejiang Chinese Medical University, Hangzhou, China

Full list of author information is available at the end of the article
Published: 1 October 2015

doi:10.1186/2197-425X-3-S1-A617

Cite this article as: Hao et al:: The effect of ulinastatin on sepsis in the rats of adhesion molecules and endothelial function. Intensive Care Medicine Experimental 2015 3(Suppl 1):A617.

\section{SpringerOpen $^{\odot}$}

(C) 2015 Hao et al.; This is an Open Access article distributed under the terms of the Creative Commons Attribution License (http:// creativecommons.org/licenses/by/4.0), which permits unrestricted use, distribution, and reproduction in any medium, provided the original work is properly cited.

Submit your manuscript to a SpringerOpen ${ }^{\circ}$ journal and benefit from:

- Convenient online submission

- Rigorous peer review

- Immediate publication on acceptance

- Open access: articles freely available online

- High visibility within the field

- Retaining the copyright to your article

Submit your next manuscript at $>$ springeropen.com 